Georgia State University College of Law Reading Room

Faculty Publications By Year

Faculty Publications

$1-1-2000$

\title{
The Scope of 'High Crimes and Misdemeanors' after the Impeachment of President Clinton
}

Neil J. Kinkopf

Georgia State University College of Law, nkinkopf@gsu.edu

Follow this and additional works at: https://readingroom.law.gsu.edu/faculty_pub

Part of the Constitutional Law Commons, Legal Remedies Commons, Litigation Commons, and the President/Executive Department Commons

\section{Recommended Citation}

Neil Kinkopf, The Scope of 'High Crimes and Misdemeanors' after the Impeachment of President Clinton, 63 Law \& Contemp. Probs. $201(2000)$.

This Article is brought to you for free and open access by the Faculty Publications at Reading Room. It has been accepted for inclusion in Faculty Publications By Year by an authorized administrator of Reading Room. For more information, please contact mbutler@gsu.edu. 


\title{
THE SCOPE OF "HIGH CRIMES AND MISDEMEANORS" AFTER THE IMPEACHMENT OF PRESIDENT CLINTON
}

\author{
NEIL KINKOPF*
}

\section{INTRODUCTION}

Constitutional theorists have begun focusing a great deal of attention on constitutionalism outside the judiciary. ${ }^{.}$As Professor Neal Katyal points out in his insightful paper, the impeachment and trial of President Clinton provide an outstanding opportunity to reflect upon the practice of constitutionalism outside the courts. ${ }^{2}$ During these episodes, the House of Representatives and the Senate confronted numerous constitutional questions, but rarely resolved them

Copyright $\odot 2000$ by Neil Kinkopf

This article is also available at http://www.law.duke.edu/journals/63LCPKinkopf.

* Assistant Professor of Law, Georgia State University.

During the Senate's trial of President Clinton, I served as Counselor to Senator Joseph R. Biden, Jr. The views expressed herein are my own and should not be attributed to Senator Biden. That said, it was a singular privilege to serve such a skilled and thoughtful constitutionalist. For helpful comments, I am enormously grateful to David Barron, Susan Low Bloch, Neal Devins, Michael Gerhardt, Janice Griffith, Paul Haagen, Lynn Hogue, William Marshall, Charles Marvin, Christopher Schroeder, and Eric Segall. I also wish to thank Lynne Voelker for excellent research assistance.

1. This conference is but one example. For other significant examples, see MARK TUSHNET, TAking THE CONSTitution AWAy FROM THE COURTS (1999); Keith E. WhitTington, CONSTITUTIONAL Construction: Divided POWERS AND CONSTITUTIONAL MEANiNG (1999).

2. See Neal Kumar Katyal, Impeachment as Congressional Constitutional Interpretation, 63 LAW \& CONTEMP. ProBs. 169 (Winter/Spring 2000). Professor Katyal contends that the courts and the political branches properly utilize different methods of constitutional interpretation. According to Professor Katyal, originalism is properly employed to constrain "unelected judges [from utilizing] an unduly free interpretive approach." Id. at $\mathbf{1 7 0 .}$. Because legislators are politically accountable, there is no countermajoritarian difficulty with allowing them to employ a more free-ranging interpretive approach. It seems dubious that originalism is more effective than any other methodology at preventing judges from imposing their own preferences. But this is a quibble that does not go to the basic assertion that, because of differing institutional attributes, Congress and the courts should interpret the Constitution differently.

It is unfortunate, however, that Professor Katyal does not address the question of judicial supremacy: "This essay does not address ... which branch has the ultimate authority to act as [the Constitution's] interpreter." Id. If we accept judicial supremacy, it will be largely futile for Congress to employ a methodology other than the judiciary's. In a world of judicial supremacy, Congress's constitutional constructions will be struck down if (1) they do not comport with the judiciary's understanding of the Constitution and (2) they yield a justiciable case or controversy, which they do in all but the most unusual circumstances. As long as Congress confronts a regime of judicial supremacy and wishes its legislative determinations to be effective, it will not pursue constitutional interpretation at odds with or asymmetrical to the judiciary's interpretation. Thus, if we accept judicial supremacy, Professor Katyal's thesis is no longer very interesting. 
on the basis of an identifiable construction of the Constitution's meaning. There is, however, at least one important question of constitutional interpretation that the House of Representatives must be understood to have resolved: the scope of impeachable offenses.

The constitutional category of impeachable offenses comprises "Treason, Bribery or other high Crimes and Misdemeanors." " The concluding phrase, "other high Crimes and Misdemeanors," is indefinite. While the matter was pending in the House of Representatives, the phrase's meaning became the subject of frequent discussion and controversy. There is broad agreement among scholars, members of Congress, and other commentators that a necessary element of any high crime and misdemeanor is great injury directly to the constitutional system of government. ${ }^{5}$ Controversy erupted over whether "high Crimes and Misdemeanors" includes an additional necessary element of an impeachable offense. The argument, based on a variety of sources, claims that the scope of impeachable offenses is further limited to official misconduct. Thus, impeachment is available only for serious public harm caused by a civil officer acting in an official capacity. Unofficial or private misconduct, it was argued, is beyond the scope of the impeachment power.

This argument was most prominently advanced by the 443 law professors who signed a letter addressed to then-Speaker of the House Newt Gingrich. The professors contended that the House should not impeach President Clinton, basing their argument primarily on the ground that a necessary element of a high crime and misdemeanor is the "grossly derelict exercise of official power." The House, by necessary implication, rejected that construction when it adopted the article of impeachment charging that President Clinton committed perjury before the grand jury, a charge that did not involve official conduct. $^{7}$

3. For example, there was much fretting over whether the Constitution permits a resolution of censure against a President. Some members of Congress expressed the view that the Constitution forbids such a resolution. Each chamber employed a parliamentary maneuver to foreclose a vote on the merits of a censure resolution. These maneuvers were not sustained exclusively or even primarily on constitutional grounds as opposed to considerations of strategy and political advantage. See generally Susan Low Bloch, A Report Card on the Impeachment: Judging the Institutions that Judged President Clinton, 63 LAW \& CONTEMP. PROBS. 143 (Winter/Spring 2000). I agree with Professor Bloch that the arguments that censure is unconstitutional are specious. See also Michael Klarman, Constitutional Fetishism and the Clinton Impeachment Debate, 85 VA. L. REV. 631, 650 (1999) (concluding that arguments by members of Congress that censure is unconstitutional changed few minds because the U.S. Const. art. II, $\$ 4$ does not resolve the issue).

4. U.S. CONST. art. II, $\S 4$.

5. See, e.g., Bloch, supra note 3, at 150 n.37; THE FEDERALIST No. 65, at 396 (Clinton Rossiter ed., 1961) (Hamilton) (noting that the remedy of impeachment is designed to redress harms that are "POLITICAL, as they relate chiefly to injuries done immediately to the society itself").

6. 144 CONG. REC. H9649-03 (daily ed. Oct. 6, 1998) (Dec. 18, 1998) (letter read into the record by Rep. Furse) [hereinafter Law Professors' Letter]. The law professors' letter is unequivocal on this point. It makes clear throughout that private or unofficial dereliction does not fall within the scope of "high Crimes and Misdemeanors." The letter concludes emphatically that "impeachment demands convincing evidence of grossly derelict exercise of official authority." Id. at H9650.

7. As the law professors' letter spells out, the perjury itself also did not relate to or seek to coverup official misconduct. See id. 
The Senate's acquittal casts some doubt on the House's judgment. Because the Senate deliberated in closed session, we do not know the actual basis of its action. It may have acquitted because unofficial misconduct cannot be a high crime or misdemeanor, or because the President's actions did not cause sufficiently grave harm to warrant impeachment, or because the charges were not proven. ${ }^{8}$

It is my contention that the House's construction is proper, notwithstanding the view of the law professors or the indeterminacy of the Senate's action. I agree with Professor Michael Gerhardt that the classic case for impeachment involves official misconduct, ${ }^{9}$ and it is not surprising that most impeachments have been predicated upon misconduct involving the exercise of official power. Even though President Clinton's misconduct was not a proper basis for impeachment or conviction, his case demonstrates that it would be terribly unwise to understand official misconduct to be a necessary element of a high crime or misdemeanor.

As Professor Bloch describes the broad agreement of the scholars who testified before the House Subcommittee on the Constitution, "to be impeachable, the actions of the President must seriously undermine the government and compromise his ability to continue governing." ${ }^{10}$ Yet, it is impossible to codify all conduct that might be so harmful. Conduct that is just as harmful to the public as treason or bribery, for example, would evade impeachability if that conduct failed to meet the technical, formal definitions of the codified offenses. In the words of Justice Joseph Story, "any attempt to define [all impeachable] offenses ... would probably tend to more injustice and inconvenience than it would correct; and perhaps would render the power at once inefficient and unwieldy." leaving the scope of impeachable offenses open-ended.

There is, however, a competing concern: According impeachable offenses a completely undefined scope raises the threat that the President will be forced to serve at the will of Congress. The Constitution's structure plainly contemplates an independent, coequal executive. The question ultimately comes down to whether this concern for the President's independence supports the argument that the scope of impeachable offenses does not include private or unofficial misconduct, but rather is limited to abuses of official power. I will begin by demonstrating that the law professors' position cannot claim substantial support from the Constitution's text, history, or structure, or from practice under the

8. The last of these grounds apparently explains the vote of Senator Arlen Specter, and the strange spectacle of his attempt to cast his vote under the forms of Scottish criminal procedure. See Helen Dewar \& Peter Baker, GOP Senators Reject Articles; Acquittal May Win Majority; Censure Ails, WASH. POST, Feb. 11, 1999, at A1.

9. See Michael J. Gerhardt, The Lessons of Impeachment History, 67 GEO. WASH. L. REV. 603 , 617-20 (1999).

10. Bloch, supra note 3, at 149; see also Donald L. Horowitz, Opinion: Interpretation, Background, Editorials, L.A. TIMES, Jan. 24, 1974, at 1.

11. JOSEPH STORY, COMMENTARIES ON THE CONSTITUTION OF THE UNITED STATES 280-81, II 396 (Ronald Rotunda \& John Nowak eds., 1987). 
Constitution. I will then argue that the impeachment of President Clinton demonstrates that the best understanding of "high crimes and misdemeanors" is that it is not limited to official misconduct.

II

\section{THE CONSTITUTION}

\section{A. Text}

In arriving at its construction of "high crimes and misdemeanors," the law professors' letter emphasizes textualization. The pertinent text reads, "the President, Vice President, and all civil Officers of the United States shall be removed from Office on Impeachment for and Conviction of Treason, Bribery, or other high Crimes and Misdemeanors." ${ }^{12}$ It is a standard canon of interpretation that general terms-here "high Crimes and Misdemeanors"-are to be understood in light of the specific terms with which they are conjoined-"Treason" and "Bribery." The force of this canon is particularly strong with respect to the Impeachment Clause because "high Crimes and Misdemeanors" is introduced by "other," which refers the reader back to treason and bribery as sources of the phrase's meaning.

The law professors' letter appropriately relies on this canon of construction. ${ }^{13}$ The common trait that defines treason and bribery is the abuse of official power because an officer who commits treason or bribery necessarily exercises official power, or so the law professors' letter reasons. Thus, the professors conclude that the scope of "high Crimes and Misdemeanors" must be limited to the derelict exercise of official power.

This argument suffers from a serious flaw. It is not a necessary element of either treason or bribery that the perpetrator exercise official power, or even hold an office..$^{14}$ Even if we limit the universe of perpetrators to civil officers of the United States, in keeping with the entirety of the constitutional text and structure, an officer may commit either treason or bribery without using official power. Imagine, for example, a federal judge who, during a declared war, gives

12. U.S. CONST. art. II, § 4.

13. See Law Professors' Letter, supra note 6, at H9649. This is no innovation. Those who have grappled with the meaning of "high Crimes and Misdemeanors" have long looked to the more definite terms "treason" and "bribery." See, e.g., EDWIN CORWIN, THE PRESIDENT: OfFICE AND POWERS 352 n.68 (1957) ("Noscitur a sociis. High crimes and misdemeanors; so high that they belong in this company with treason and bribery.").

14. Professor Laurence Tribe has observed that bribery always involves the misuse of some office, even if not necessarily an office held by the one offering the bribe. See Laurence H. Tribe, Defining "High Crimes and Misdemeanors": Basic Principles, 67 GEO. WASH. L. REV. 712, 726-27 (1999). Accepting such a broad view of official misconduct would undermine the conclusion offered by Professor Tribe and the law professors' letter, because lying to a grand jury or in a deposition can cause the grand jury or a judge to act in a way that these officials would not otherwise have acted (granting or denying summary judgment or an indictment, for example). Moreover, Professor Tribe's description highlights a feature that bribery does not share with treason. The necessary effect of treason is giving aid and comfort to the enemies of the United States; but treason does not necessarily affect any office of the United States, although it certainly could. 
a series of speeches condemning the United States, admiring the declared enemy nation, and urging all listeners to support the enemy's cause. ${ }^{15}$ This conduct would be treason, though the judge never put his or her office to the service of the enemy. It also is not difficult to imagine an officer who is a party to a judicial proceeding in his or her private capacity seeking to bribe the judge. ${ }^{16}$ The exercise of official power, then, is not a necessary element of either bribery or treason, even when committed by a civil officer or the President of the United States.

Treason and bribery nevertheless are similar in one important respect-the harm that each crime threatens. Regardless of how it might be perpetrated, each crime threatens to cause serious injury "immediately to the society itself." The Constitution defines treason largely in terms of harm: levying war against the United States or giving adherence or aid and comfort to the enemies of the United States. ${ }^{18}$ Whenever anyone, including a civil officer, commits bribery or treason, an immediate harm directly to the constitutional system of government is threatened. In cases of treason, the threat goes to the very existence of our constitutional system of government. Applying this common element to "high Crimes and Misdemeanors," the text supports a reading of those terms focused not on the official or private nature of the misconduct, but on the nature of the harms that flow from the misconduct.

I do not contend that a focus on the text of the Impeachment Clause alone yields a definitive meaning of the phrase. While it is possible and even foreseeable that an officer, including the President, might commit treason or bribery without exercising official power, it seems likely that the more common or paradigmatic case would involve the abuse of such power. It is thus conceivable that the implications of bribery and treason are limited to this more paradigmatic case. The Constitution's text alone does not compel this construction and, in fact, tends to undermine it.

\section{B. Structure}

This inquiry-whether unofficial conduct can constitute impeachable offenses-is too specific to expect the Constitution's structure to divulge an unambiguous answer. Nevertheless, its structure does offer some general direction. First, the Constitution plainly creates an independent and coequal executive. The executive is designed as a distinct branch of the government

15. This closely resembles the conduct charged in one of the articles of impeachment against Judge West Humphreys. The case of Judge Humphreys is discussed infra at Part II.D.2.

16. 145 Cong. Rec. S281, 292 (Jan. 16, 1999) (statement of Rep. Canady). The letter attempts a linguistic dodge. It contends that when the President commits treason or bribery, he will necessarily abuse his office. It is difficult, though not impossible, to imagine a President committing treason in a way that does not involve his misuse of the commander-in-chief power or some other power of office. Having learned that a President may be subject to a civil lawsuit while in office, see Clinton v. Jones, 520 U.S. 681 (1997), it is not difficult to conceive of a President having the occasion and incentive to offer a bribe to put an end to such a suit.

17. THE FedERalist No. 65, at 396 (Clinton Rossiter ed., 1961).

18. See U.S. CONST. art. III, $\$ 3$. 
with its power vested in the President. As a result, the President's core power derives not from another branch of government, but from the Constitution itself. The President, similarly, is not elected by another branch of the federal government and so does not owe his or her position to the other branches. ${ }^{19}$ The President's salary, once fixed, may not be altered during the President's term in office. ${ }^{20}$ Similarly, the President's term is fixed and may not be expanded or curtailed, except in the case of impeachment and conviction. ${ }^{21}$ At its essence, neither the presidency nor the President depends on Congress or, for that matter, the judiciary.

Yet, the Constitution does not establish the executive branch as unqualifiedly independent. The President, for example, must look to Congress for appropriations and to the Senate to ratify treaties and confirm the Cabinet and other significant appointees. ${ }^{22}$ The Constitution specifically provides impeachment as a mechanism by which Congress may remove the President and civil officers of the executive branch, among others. This indicates that concern for executive independence should not be made into a fetish. An exclusive focus on independence would lead to construing the category of "high Crimes and Misdemeanors" to be a null set.

The Constitution's structure, as it so often does, points to balance. On the one hand, the impeachment power must be interpreted in a manner consistent with the essential independence of the executive branch. On the other hand, executive independence should not be over-emphasized to the detriment of maintaining an effective impeachment mechanism. The Constitution's structure thus channels the inquiry, but does not provide an answer.

\section{History}

One searches the records of the founding era in vain for statements directed to this question. That the founders paid so little attention to the definition of "high Crimes and Misdemeanors" is not nearly so surprising as it might initially seem. A striking feature of the Constitution is the nearly complete lack of definitions. The document leaves undefined such crucially important terms as "executive power," "legislative power," and "judicial power."

James Madison, by any reckoning a leading constitutionalist of the founding era, was quite vigilant about asserting and protecting the independence of the presidency. He was committed to creating an impeachment mechanism that would not become an instrument of congressional domination over the executive branch. ${ }^{24}$ There is no record, however, that Madison ever considered or

19. Only in the extraordinary event that the electoral college fails to yield a President does the choice fall to Congress. See U.S. Const. amend. XII; id. amend. XX.

20. Id. art. II, $\$ 1$.

21. Id.

22. See id. art. I, $\S 9, \mathrm{cl} .7$ (appropriations); id. art. II, $\S 2, \mathrm{cl} .2$ (ratification and confirmation).

23. In a rule-proving exception, the Constitution does define "treason." See id. art. III, $\S 3$.

24. See infra text accompanying note 31 . 
suggested that presidential independence be protected by imposing categorical limits on the scope of impeachable offenses. This view is perfectly consistent with the general approach to the separation of powers that Madison set forth in The Federalist. ${ }^{25}$ He disdained "parchment barriers" on constitutional power because such definitional limitations would prove to be ineffectual; the only way to limit power meaningfully was by establishing a structure of countervailing powers. ${ }^{26}$ As Madison's disdain for formalistic limits on governmental power was common among those who debated the Constitution, it is not surprising that the debates focused on the structure of the impeachment power and its place in the system of checks and balances, rather than on the definition of impeachable offenses.

It is possible, nevertheless, to find comments from the constitutional debates to the effect that egregiously harmful abuses of official power are high crimes and misdemeanors. It is also possible to find comments that offer such misconduct as the paradigmatic case of an impeachable offense. ${ }^{27}$ None of these comments, however, includes a claim of exclusivity, and comment was made in the context of a discussion of the definition of "high Crimes and Misdemeanors." To its credit, the law professors' letter does not assert that history supports its position. Others who have taken this position, notably President Clinton's defense team, place substantial reliance on founding era history. ${ }^{28}$

1. The Federal Convention. A familiar adage holds that a page of history is worth a volume of logic. Be that as it may, the discussion that led to the adoption of the phrase "high Crimes and Misdemeanors" takes up less than a

25. Madison's view is reflected in the Constitution's structure and continues to inform our understanding of that structure.

26. Hence, the Constitution's enduring innovation is not so much the way it separates power, but the way it intermixes power to create a system of checks and balances. See generally THE FEDERALIST Nos. $47-48,51$.

27. See, e.g., 2 THE RECORDS OF THE FEDERAL CONVENTION OF 1787, at 65-66 (Max Farrand ed., 1966) (comments of James Madison); id. at 67 (comments of Edmund Randolph); James Iredell on the Presidency, Spies, the Pardoning Power, and Impeachment, in 2 DEBATE ON THE CONSTITUTION 873 (Bernard Bailyn ed., 1993) ("If he commits any misdemeanor in office, he is impeachable, removable from office, and incapacitated to hold any office of honour, trust, or profit"); Brutus XV, N.Y.J. (Mar. 20, 1788), in DEBATE ON THE CONSTITUTION, supra, at 375. Even such statements have at least some degree of ambiguity. It is not absolutely clear, for example, that a misdemeanor in office refers exclusively to an abuse of the powers of an office, in contrast to an unofficial act taken during an officer's tenure that results in significant public harms.

It is similarly no great feat to locate statements that phrase the grounds for impeachment in terms broad enough to include private, unofficial misconduct. For example, Benjamin Franklin argued that the possibility of impeachment would be an advantage to the President because it could function as an alternative to assassination in cases "where the Chief Magistrate had made himself obnoxious." 2 THE RECORDS OF THE FEDERAL CONVENTION OF 1787, supra, at 65.

28. See Submission by Counsel for President Clinton to the Committee on the Judiciary of the United States House of Representatives, 98 WL 856898 (Dec. 8, 1998) [hereinafter Clinton Submission]; see also Cass Sunstein, Impeachment and Stability, 67 GEO. WASH. L. REV. 699, 700-03 (1999). Those opposing the President's position also performed dazzling historical recovery. See, e.g., Gary L. McDowell, High Crimes and Misdemeanors: Recovering the Intentions of the Founders, 67 GEO. WASH. L. REV. 626, 630-35 (1999). 
page of Madison's notes ${ }^{29}$ and ultimately sheds no light on the phrase's meaning. ${ }^{30}$ Such a brief passage can be reproduced in its entirety:

Col. Mason. Why is the provision restrained to Treason and bribery only? Treason as defined in the Constitution will not reach many great and dangerous offences. Hastings is not guilty of Treason. Attempts to subvert the Constitution may not be treason as above defined. As bills of attainder which have saved the British constitution are forbidden, it is the more necessary to extend: the power of impeachments. $\mathrm{He}$ moved to add after "bribery" "or maladministration." Mr. GERRY seconded him.

Mr. Madison. So vague a term will be equivalent to a tenure during pleasure of the Senate.

Mr. Gouvernour Morris, it will not be put in force \& can do no harm. An election of every four years will prevent maladministration.

COL. MASON withdrew "maladministration" and substitutes "other high crimes and misdemeanors agst. the State." 31

The category "maladministration" was understood to be limited to offenses involving the exercise of office. ${ }^{32}$ Hence, one plausible interpretation of the Mason-Madison exchange is that the rejection of maladministration represented a rejection of this limitation. This appears to be the position of Raoul Berger. ${ }^{33}$

The exchange can be just as easily read to support the opposite conclusion: Maladministration was limited to official misconduct. The reason for rejecting this term was that it was too broad. If "high Crimes and Misdemeanors" narrows the scope of impeachable misconduct from that covered by maladministration, it cannot include unofficial misconduct, for that would expand maladministration.

A close reading of the Mason-Madison exchange discloses that it does not support either view. First, the Convention itself did not reject the term "maladministration." Mason introduced the term and withdrew it after hearing Madison's objection. Because there was no vote, there was no opportunity for the delegates to adopt or reject Madison's concern. Second, according to Blackstone, British common law had developed a definition of "high Crimes

29. Before this consideration, the convention held one lengthy discussion of impeachment, which centered on whether to include an impeachment mechanism. Those who spoke in favor of a mechanism recognized the capacity of a chief magistrate to injure the nation and emphasized the need for protection against such injury. Some gave specific examples of the types of harms that most dramatically illustrated the need for an impeachment remedy. The litany of examples typically included the betrayal of the nation to foreign powers and bribery and corruption. James Madison came closest to offering a list of impeachable offenses, including incapacity, negligence, or perfidy. See 2 THE RECORDS OF THE FEDERAL CONVENTION OF 1787, supra note 27, at 65 . Madison plainly did not mean this list as a definition of the proper grounds for impeachment. As his colloquy with Mason on September 8, 1787, indicates, Madison would have opposed negligence as a ground for impeachment. Indeed, none of those who spoke on July 20, 1787, purported to offer a definition of the permissible grounds for impeachment. Instead, the comments were directed to the broader question of whether the chief executive should be subject to impeachment at all. See id.

30. Thus, I do not delve into the question whether the Philadelphia debates are a legitimate source of constitutional meaning.

31. 2 THE RECORDS OF THE FEDERAL CONVENTION OF 1787, supra note 27, at 550 .

32. See IV William Blackstone, COMMENTARIES ON THE LAWS OF ENGLAND 121 (1765); IV JAMES STEPHEN, NEW COMMENTARIES ON THE LAWS OF ENGLAND 279 (6th ed., 1868).

33. See Raoul Berger, Impeachment: The Constitutional Problems 193-213 (1973). 
and Misdemeanors" that included but was not limited to "maladministration." 34 The phrase also encompassed unofficial misconduct. While Madison may not have known this, Mason apparently knew at least that it encompassed maladministration. ${ }^{35}$ Thus, Mason may have thought he had snookered Madison. ${ }^{36}$ In any event, neither Madison nor Mason expressed his definition of the phrase. As there was no construction of the phrase offered on the floor before the vote, it remains completely unclear what the state delegations that voted on it may have thought the phrase meant or whether they even had a common understanding of its meaning.

The Convention discussed the question of impeachment at length on one other occasion. On July 20, 1787, the delegates debated the proposal that the President "be removable on impeachment and conviction for malpractice or neglect of duty." 37 The debate that followed did not center on the issue of the proper grounds for impeachment, but on whether the President should be impeachable at all. Rufus King and Charles Pinckney argued against extending the impeachment power to cover the President. ${ }^{38}$ They were initially joined by Gouvernour Morris, though he later conceded that impeachment might be an appropriate response to some offenses. ${ }^{39}$

Speaking in favor of a power of presidential impeachment were William Davie, James Wilson, George Mason, Benjamin Franklin, James Madison, Elbridge Gerry, and Edmund Randolph. Impeachment, for this group of speakers, was necessary to protect against presidential misconduct that they variously deemed "great crimes" and "corruption" (Mason); "render[ing] himself obnoxious" (Franklin); "incapacity, negligence or perfidy" (Madison) $;^{42}$ and "treachery," "[c]orrupting his electors," and "incapacity" (Morris). ${ }^{43}$ At least some of these formulations_great crimes, obnoxiousness, and perfidy-are not limited to official misconduct. Even if they were, they are not offered as part of

\footnotetext{
34. See IV BLACKSTONE supra note 32.

35. See Peter Charles Hoffer \& N.E.H. Hull, Impeachment in AmEriCA 1635-1805, at 101
} (1984).

36. While Mason apparently did not share Madison's concern that the impeachment device would undermine the independence of the executive branch, Mason did share Madison's substantive concern that executive independence be preserved. Early in the Convention, Mason opposed a motion to subject the executive to removal by the legislature. According to Madison's notes, Mason thought that "[s]ome mode of displacing an unfit magistrate is rendered indispensable by the fallibility of those who choose, as well as by the corruptibility of the man chosen. [Mason] opposed decidedly making the Executive the mere creature of the legislature as a violation of the fundamental principle of good Government." See 1 THE RECORDS OF THE FEDERAL CONVENTION OF 1787, supra note 27, at 86. Whatever Mason's strategy might have been, Madison apparently was aware that maladministration was encompassed within high crimes and misdemeanors. See 12 PAPERS OF JAMES MADISON 235, 238 (1979).

37. 2 THE RECORDS OF THE FEDERAL CONVENTION OF 1787, supra note 27, at 64 .

38. Id. at 66-67.

39. Id. at 68-69.

40. Id. at 65 .

41. Id.

42. Id.

43. Id. at 69 . 
an attempt to define the scope of impeachable offenses. In the context of the discussion, they are each speaker's attempt to articulate the strongest case for subjecting the President to the impeachment power. In light of his subsequent exchange with Mason, it is doubtful Madison would have accepted mere negligence as a basis for presidential impeachment. It is therefore doubtful that the speakers on July 20,1787 , meant their expressed formulations to be understood as bearing on the scope of the impeachment power, rather than merely portraying the possibility of serious misconduct.

2. The State Ratification Debates. As with the convention in which the Constitution was drafted, the debates in the states over whether to ratify the Constitution raised no specific discussion of the scope of impeachable offenses. Consistent with Madison's approach to separation of powers, these debates focused on the structure of the impeachment power and, in particular, on the role of the Senate.

Many prominent opponents of ratification fixed upon impeachment as one of the Constitution's objectionable features. Yet none ever objected to the scope of impeachable offenses. Largely as a consequence, those who supported ratification did not address the scope of "high Crimes and Misdemeanors." Anti-federalists aimed their criticisms at the structure of the impeachment power and, in particular, on the Senate's power to try impeachments. These criticisms proceeded from an expectation, which turns out to have been erroneous, that the Senate and the President would enjoy a cozy relationship stemming from the Senate's advice-and-consent role in relation to the significant executive powers of appointment and treaty-making. Antifederalists concluded that this relationship would prevent impeachment from operating as a meaningful check against presidential abuse. ${ }^{4+}$

44. This complaint was voiced repeatedly during the pivotal debate in New York. For example, Arthur Lee thought the Senate a thoroughly objectionable aristocracy that would be used by the President "so as to make that body at once the instrument of and the shield of his absolute authority." Arthur Lee, Cincinnatus $V$ (Nov. 29, 1787), in 1 THE DeBate on THE ConstituTion 114 (Bernard Bailyn ed., 1993). Lee thus thought little of the Senate's role in impeachment:

We have seen with what cunning the power of impeachment is apparently given to the representative of the people, but really to the senate; since, as they advise these measures of government, which experience has shewn, are the general matters of impunity the executive officers will be sure of impeachment when they act in conformity with their will. Impeachment will therefore have no terrors, but for those who displease or oppose the senate

Id. The Federal Farmer echoed Lee's objection:

All officers are impeachable before the Senate only before the men by whom they are appointed, or who are consenting to the appointment of these officers. No judgment of conviction on an impeachment can be given unless two-thirds of the senators agree. Under these circumstances the right of impeachment, in the house, can be of but little importance: the house cannot expect often to convict the offender; and therefore probably will but seldom exercise or never exercise the right.

The Federal Farmer, Letter III (Oct. 10, 1787), in 1 THE DEBATE ON THE CONSTITUTION, supra, at 265.

The same dissent was raised in the Pennsylvania convention where the minority of delegates who opposed the Constitution issued a report contending that the intermingling of the President and Senate "may bias the judgment of the senators, and tend to screen great delinquencies from punishment." Dissent of the Minority of the Pennsylvania Convention (Dec. 18, 1787), in 1 THE DEBATE ON THE 
The records of the state ratification debates are nearly devoid of discussion of the scope. Some who advocate limiting the scope to official misconduct cite comments by James Wilson in the Pennsylvania ratifying convention and James Iredell in North Carolina. ${ }^{45}$ Neither supports the position.

During the Pennsylvania debates, James Wilson, a delegate in Philadelphia and a future Justice of the Supreme Court of the United States, reassured the state ratifying convention that impeachment could be grounded only on "great

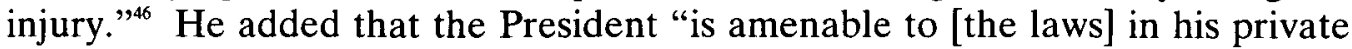
character as a citizen, and in his public character by impeachment. ${ }^{\prime 47}$ Attempts to read these statements to limit "high Crimes and Misdemeanors" to official misconduct are unpersuasive.$^{48}$ Wilson focused on the degree of harm caused to the nation-"great injuries"- not on whether the harm resulted from the exercise of official power. In pointing out that the President is not above the law, Wilson referred to the President being amenable to legal redress "in his public character by impeachment." ${ }^{\text {"49 }}$ Wilson did not employ this formulation to distinguish official from unofficial misconduct. Instead, he referred to the nature of the sanction. The President's impeachment and conviction can carry only public punishments - removal from office and disqualification ${ }^{50}$ - while private sanctions - fines, imprisonment, and the like - can result only from ordinary criminal proceedings before the judiciary. ${ }^{\text {st }}$ Wilson simply was not addressing whether the category "high Crimes and Misdemeanors" is limited to officiai misconduct.

James Iredell was, like Wilson, a delegate at Philadelphia and later a Justice of the Supreme Court. During the North Carolina ratification debates, he echoed Wilson's concern that impeachment be available to remedy serious harms to the nation. Impeachment, he envisioned, would "arise from acts of great in-

CONSTITUTION, supra, at 546. In Maryland, Luther Martin objected to the role of the House as well as that of the Senate. He believed that House members would be obsequious toward the President to secure appointment to federal office. He added that if a President were impeached, the Senate would be unlikely to convict the President both because of a desire for appointment to an office and because of its role in advising the President on appointments and treaties. See Luther Martin, The Genuine Information IX (Jan. 29, 1788), in 1 THE DEBATE ON THE CONSTITUTION, supra, at 654-55.

45. See Clinton Submission, supra note 28 , at 10.

46. 4 ELLIOTT'S DEBATES 113.

47. Id. at 480 .

48. For an important effort at such a reading, see Clinton Submission, supra note 28 , at 10 . The preceding quote from James Wilson, along with the insertion, is taken from this submission.

49. See 4 Elliott's Debates at 480 ..

50. See U.S. Const. art. I, $\S \mathrm{X}$. There is some question as to whether punishments that are lesser, and thus do not extend further, than removal and disqualification are permissible. Some have also contended that an officer may be impeached and convicted on grounds other than "Treason, Bribery, or other high Crimes and Misdemeanors" and that conviction on such grounds may alter the punishment landscape. See Joseph Isenbergh, Impeachment and Presidential Immunity from Judicial Process (Dec. 31, 1998) (unpublished article, on file with University of Chicago School of Law, Occasional Paper No. 39); Joseph Isenbergh, Impeachment and Presidential Immunity from Judicial Process, 18 YALE L. \& POL'Y REV. 53 (1999); Douglas W. Kmiec, Editorial, Convict, But Don't Remove Clinton, WALL ST. J., Jan. 29, 1999, at A14.

51. Elsewhere, Wilson refers to the political punishments that follow impeachment and conviction. See THE WORKS OF JAMES WILSON 426 (1967). 
jury to the community. ${ }^{\$ 2}$ Iredell's emphasis was on the nature and degree of the injury, that it harm the community and that it be serious, and not on the nature of the wrongdoing that gave rise to the harm. Nevertheless, Iredell added, "I suppose the only instances in which the President would be liable to impeachment would be where he had received a bribe or had acted from some other corrupt motive." ${ }^{53}$ This is as close as anyone speaking during the ratification debates ever came to articulating the official misconduct position. However, placing the comment in its context reveals that it is not an endorsement of that view.

Iredell made this remark during the North Carolina ratification convention and in direct response to the argument of Samuel Spencer against ratification. Spencer had articulated the common antifederalist argument that the impeachment power would be ineffectual: The Senate would never impeach the President because the President's conduct would be governed by the Senate's advice and consent. ${ }^{54}$ Iredell characterized the argument and responded to it:

[The impeachment mechanism] is objected to as improper, because if the President or Senate should abuse their trust, there is not sufficient responsibility, since he can only be tried by the Senate, by whose advice he acted; and the Senate cannot be tried at all. I beg leave to observe that when any man is impeached, it must be for an error of the heart, and not of the head. God forbid that a man in any country in the world should be liable to be punished for want of judgment. This is not the case here. ${ }^{55}$

Iredell's supposition is offered to clarify the distinction between errors of the heart and those of the head. Errors of the heart involve improper motives while errors of the head involve poor or mistaken judgment. The exchange between Spencer and Iredell plainly involves the scope of impeachable offenses, but it relates to the question of which official misdeeds fall within that scope. It does not address the question of whether the scope encompasses only official misdeeds. By phrasing his response as a supposition, Iredell himself was careful not to express a conclusion on any question other than the one specifically under discussion.

The Federalist also fails to clarify whether the category of "high Crimes and Misdemeanors" is limited to official misconduct. Impeachment receives sustained consideration in two numbers, each written by Alexander Hamilton. Reflecting the dominant theme of the ratification debates, Hamilton's inquiry centers on the structural aspects of impeachment, particularly the decision to grant exclusively to the Senate the power to try impeachments. The meaning of "high Crimes and Misdemeanors" is not discussed separately and is considered only insofar as it sheds light on the propriety of the Senate's judicial role in impeachments. In the passage most nearly directed to the meaning of the category, Hamilton focuses on the nature of the injury rather than on the nature of

52. 4 ELLIOTT'S DEBATES 113.

53. Id.

54. See Samuel Spencer Objects to the Powers of the Senate and Fears It Will Control the President (July 28, 1788), in 2 THE DEBATE ON THE CONSTITUTION, supra note 27, at 879-81.

55. Id. at 882 . 
the conduct giving rise to the injury: "[Impeachable offenses] are of a nature which may with peculiar propriety be denominated POLITICAL, as they relate chiefly to injuries done immediately to the society itself." cusses impeachable offenses as involving "the misconduct of public men," as opposed to the public misconduct of public men or the official misconduct of public men. ${ }^{57} \mathrm{He}$ illustrates this phrase by remarking that impeachable offenses proceed "from abuse or violation of some public trust." In context, it is ambiguous whether violating a public trust refers to an abuse of the powers of an office or to any misconduct of an officer that directly injures the society itself.

It would be fair to criticize this recapitulation of The Federalist for parsing its language too finely. This language, after all, is not meant to define "high Crimes and Misdemeanors." Moreover, nowhere does The Federalist address itself to the question of whether impeachable offenses are limited to certain types of misconduct. ${ }^{58}$ Thus, even if it could be established that abuse of some public trust refers only to official misconduct, it would be a leap to understand Hamilton to have meant that official misconduct alone could serve as a predicate for impeachment. As he was not discussing that issue, Hamilton may have meant simply to employ a shorthand that encompassed what he anticipated would be the typical case.

3. Early Commentators. Those who wrote about the Constitution's meaning in the decades soon after its ratification did not resolve the matter. One early commentator, William Rawle, took the position that the scope of "high Crimes and Misdemeanors" is limited to official misconduct. He claimed that impeachable offenses

can only have reference to public character and official duty .... In general those offenses which may be committed equally by a private person as a public officer, are not the subjects of impeachment. Murder, burglary, robbery, and indeed all offences not immediately connected with office, except the two expressly mentioned, are left to the ordinary course of judicial proceeding, and neither house can regularly inquire into them, except for the purpose of expelling the member. ${ }^{59}$

Rawle, however, offered no historical or textual analysis to support his position. ${ }^{60}$ Indeed, his position did not represent an uncontroversial reflection of a

56. THE FEDERALIST No. 65, at 396.

57. See id.; see also id. at 397 (discussing the conduct of "public men").

58. Of course, even where Hamilton directly and plainly expressed his understanding as to an open question of the Constitution's meaning, that understanding has not governed the resolution of the question. See id. No. 77 (expressing the view that the concurrence of the Senate would be required to displace officers appointed by and with the advice and consent of the Senate). But see Myers v. United States. 272 U.S. 52 (1926) (holding unconstitutional the requirement that the President receive the advice and consent of the Senate before removing a postmaster first class).

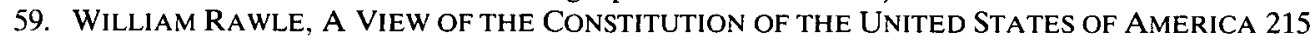
(1825).

60 . The only support distinguishing his view from bare assertion was a brief summary of early practice. Rawle noted that the first impeachment-of Senator Blount-is ambiguous because the Senate did not render a decision on the merits. See id. As discussed infra, this is not an accurate description of the Senate's action. Its decision may or may not have been on the merits, but because several alternative grounds for acquittal were advanced and the deliberations have never been made public, we do not 
broad, early consensus of the meaning of "high Crimes and Misdemeanors." Shortly after Rawle's treatise appeared, Justice Joseph Story published his own. Justice Story observed Rawle's position, but asserted that the question had not been settled. ${ }^{61}$

$$
* * * * *
$$

It is not surprising that the drafting and ratification debates do not pay substantial attention to defining the scope of impeachable offenses, given the founding generation's inclination to focus on the structure of power, rather than defining its content. There is a second reason that the founding generation did not seek to define "high Crimes and Misdemeanors." They recognized that any attempt to define impeachable offenses would undermine the effectiveness of the impeachment power. Consequently, the scope of impeachable offenses was left open to allow for common law development, by Congress, rather than the courts. $^{62}$

Alexander Hamilton contrasted the nature of impeachment with that of typical judicial proceedings. Impeachments "can never be tied down by such strict rules, either in the delineation of the offense by the prosecutors [the House] or in the construction of it by the judges [the Senate]., ${ }^{, 63}$ Joseph Story explained the reasoning:

Any attempt to define the offences, or to affix to every grade of distinction its appropriate measure of punishment, would probably tend to more injustice and inconvenience, than it would correct; and perhaps would render the power at once inefficient and unwieldy.... [I]ndeed, political offences are of so various and complex a character, so utterly incapable of being defined, or classified, that the task of positive legislation would be impracticable, if it were not almost absurd to attempt it.

This reflects the concern that moved George Mason to propose expanding the category of impeachable offenses beyond treason and bribery. ${ }^{65}$ Specifically, there was a need to reach misconduct that would be just as harmful as treason or bribery, but would not satisfy the technical definition of those or any specifically enumerated crime. Given this concern, it is not surprising that the Constitution embodies language that does not codify clear, formal elements of an impeachable offense.

know the basis of the decision. The next two impeachments were, according to Rawle, based on charges of official misconduct. See id.

61. 2 JOSEPH STORY, COMMENTARIES ON THE CONSTITUTION OF THE UNITED STATES IIT 799. 800 (1991).

62. See Michael J. Gerhardt, The Federal ImPeachment Process: A Constitutional AND HISTORICAL ANALYSIS 105-06 (1996).

63. THE FEDERALIST NO. 65, at 398. James Iredell seems to have agreed. "[T]he occasion for its exercise will arise from acts of great injury to the community, and the objects of it may be such as cannot be easily reached by an ordinary tribunal." The Presidency, Spies, the Pardoning Power, and Impeachment (July 28, 1788), in 2 DEBATE ON THE CONSTITUTION, supra note 27 , at 877.

64. STORY, supra note 61, III 396, 404; see also id. II 405 ("[W] [Wat are, and what are not high Crimes and Misdemeanors, is to be ascertained by a recurrence to that great basis of American jurisprudence, [the common law].").

65. See supra text accompanying notes $29-43$. 


\section{Practice}

The practical construction given to a constitutional provision by the branches charged with carrying out the provision can also shed light on the meaning of uncertain constitutional language. Such precedent is most helpful when it reflects an interpretation applied consistently since the ratification. ${ }^{66}$ Because impeachment issues have arisen only sporadically, there is no such precedent. Congress has, however, faced the question whether the scope of impeachment encompasses unofficial misconduct. Before the Clinton impeachment, on three occasions the House of Representatives has impeached, and twice the Senate has convicted, an official on the basis of unofficial misconduct. $^{67}$ Neither chamber has ever expressed approval of the official misconduct position.

1. William Blount. The first federal impeachment involved exclusively unofficial conduct. William Blount was an original United States senator from Tennessee. In addition, Blount was an important land speculator. In an outlandish and ill-defined scheme, Blount attempted to incite the Cherokee and Creek Indians to displace the Spanish authorities from their control over land stretching from what is now Florida through what is now Louisiana. Blount then planned to make a major land sale to Great Britain. President Adams exposed the plot, which threatened American neutrality in the conflict between Britain and Spain, to Congress. The House of Representatives quickly voted to impeach Senator Blount, but before it drafted and presented the articles of impeachment, the Senate voted to expel him. ${ }^{68}$ Undeterred, the House drafted and approved five articles of impeachment. These articles did not cite a single instance in which Blount used his position as a senator to further his plot. The articles instead asserted that Blount committed high crimes and misdemeanors by undertaking a course of conduct that threatened American neutrality and peace, and potentially placed the United States in violation of treaty obligations. The threat of these consequences violated "the duty of his trust and station as a senator of the United States."

In the Senate, Blount proffered three defenses to the articles of impeachment. He relied principally upon the argument that the position of senator is not a civil office of the United States. Blount also argued that, even if a senator is an officer of the United States, he was no longer an officer because he had been expelled from the Senate. Finally, Blount argued that because his conduct did not involve the use of his office, it could not fall within the scope of "high Crimes and Misdemeanors." The Senate voted to dismiss the articles of imring).

66. See Youngstown Sheet \& Tube v. Sawyer, 343 U.S. 579, 613 (1952) (Frankfurter, J., concur-

67. Judges West Humphreys and Harry Claiborne were impeached and convicted. Senator William Blount was impeached, but the Senate voted to dismiss the articles of impeachment.

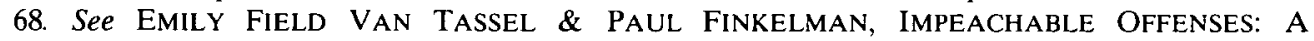
DoCUMENTARY History FROM 1787 TO THE PRESENT 87 (1999).

69. Id. at $88-90$. 
peachment. Because they deliberated in closed session, there is no record to establish the grounds on which the Senate granted the dismissal. ${ }^{70}$ It is, therefore, not clear what view the Senate took with respect to the scope of "high Crimes and Misdemeanors." Nevertheless, Blount's arguments confirm that the House had voted to impeach on the basis of unofficial conduct.

2. West Humphreys. Tennessee also yields the second case of an impeachment based on unofficial conduct, but, in this case, the Senate voted to convict. West Humphreys was a federal judge in Tennessee when the Civil War broke out. He engaged in a course of conduct that demonstrated his loyalty to the Confederacy, although he never formally resigned from the federal bench. The House of Representatives drafted seven articles of impeachment against Humphreys, and convictions were voted on all seven. ${ }^{1}$

With the exception of the fifth article,$^{12}$ no article of impeachment against Judge Humphreys alleged any abuse of the powers of his federal office. ${ }^{3}$ The first article charged that Humphreys made speeches inciting revolt and rebellion against the government of the United States. ${ }^{74}$ The second article asserted that, "together with other evil-minded persons," Humphreys supported and advocated Tennessee's secession from the Union. ${ }^{75}$ The third article alleged that Humphreys had conspired to organize armed rebellion against the United States. The fourth article cited Humphreys as having conspired to oppose by force the authority of the United States. ${ }^{76}$

The impeachment and conviction of West Humphreys is telling. Nowhere did the first four articles of impeachment refer to conduct that involved the exercise of any power of Humphreys's judicial office. ${ }^{77}$ Yet, those articles expressly contend that Humphreys's unofficial conduct violated his public trust and represented "high Crimes and Misdemeanors."

70. The Blount impeachment and trial are recounted in DAVID P. CURRIE, THE CONSTITUTION IN CONGRESS: THE FEDERALIST PERIOD, 1789-1800, at 275-81 (1997). The Senate's vote is nevertheless often understood to establish Blount's principal argument-that senators are not officers. See VAN TASSEL \& FINKELMAN supra note 68, at 86-88; 2 STORY, supra note 61, at 259, II 791; RAWLE, supra note 59, at 213-14.

71. The sixth article was subdivided into three specifications. He was convicted of the first and third, but acquitted of the second, which charged him with ordering the confiscation, for the benefit of the Confederacy, of the property of two Tennesseans who remained prominently loyal to the Union, Associate Justice of the United States John Catron and United States Senator Andrew Johnson. See VAN TASSEL \& FINKELMAN, supra note 68, at 115, 118.

72. The fifth article plainly alleged official misconduct. It charged that beginning on July 1, 1861, Humphreys abandoned his federal duties and ceased holding court. See id. at 118.

73. See id. at 117-19.

74. See id. at 117.

75. Id.

76. See id.

77. See id.

78. See id. It may be tempting to dismiss the Humphreys precedent as involving treason, but it is also important to bear in mind that the articles did not allege treason, although they borrow heavily from the language of treason. See id. at 116. Moreover, understanding Humphreys to have been impeached and convicted of treason would have significant implications for the textual argument. See supra text accompanying notes 12-18. If Humphreys was impeached and convicted for treason, this would 
tatives adopted each of these articles separately, representing its judgment that the offense alleged in each article is, standing alone, a sufficient basis for impeachment. Consistent with the House's action, the Senate voted separately to convict Humphreys on each article of impeachment. Once the Senate voted to convict on the first article of impeachment, which alleged that Humphreys made a speech in support of rebellion against the United States, Humphreys was automatically removed from office, regardless of the outcome of the remaining articles including the fifth, which did involve an abuse of office claim. ${ }^{79}$

3. Harry Claiborne. Federal District Judge Harry Claiborne was prosecuted and convicted of underreporting his income, and thereby making false statements to the Internal Revenue Service for the calendar years 1979 and $1980 .^{80}$ For other calendar years, Claiborne had been charged with receiving bribes and underreporting his income by the amount of these bribes. Claiborne was acquitted of all charges relating to bribery or failing to report the income received from bribes. The counts of which he was convicted were wholly unrelated to any misconduct on the bench or any improper use of the judicial office. Despite his criminal conviction, Claiborne refused to resign his office, much as West Humphreys had done. Faced with the spectacle of a federal judge drawing his pay and formally holding his office while sitting in jail, the House impeached Claiborne on four articles. ${ }^{81}$ The Senate voted to convict on three. ${ }^{82}$ None of the articles charged Claiborne with misconduct relating to his office, except in that his unofficial conduct was incompatible with his continued service as a federal judge as having brought disrepute on the federal judiciary. This case plainly establishes a precedent that unofficial misconduct may be a high crime or misdemeanor.

4. Richard Nixon. The case of President Richard Nixon is sometimes raised in support of the proposition that impeachable conduct must involve abuse of official power. ${ }^{83}$ The House Judiciary Committee adopted articles of impeachment charging President Nixon with massive abuse of his official

confirm that an officer can commit impeachable treason even though the officer did not exercise any official power in committing the treason.

79. See Cong. Globe, 37th Cong., 2d Sess. 29, 49-50 (1862).

80. See VAN TASSEL \& FINKELMAN supra note 68 , at 169.

81. See id. at 170. The first article alleged his 1979 tax evasion, the second his 1980 tax evasion, the third asserted the simple fact of his criminal conviction as an independent ground, and the fourth cited Claiborne for "bringing disrepute on the [f]ederal courts and the administration of justice." Id. at 17072.

82. The Senate rejected the article asserting the mere fact of conviction was a high crime and misdemeanor. Although the vote was 46-17 in favor of conviction, the Constitution requires the concurrence of two-thirds of the members present. As there were 97 senators present, the article failed to draw the required two-thirds majority, even though it drew more than two-thirds of those senators who actually voted.

83. See White House Submission, supra note 28; Cass Sunstein, Impeachment and Stability, 67 GEO. WASH. L. REV. 699 (1999). 
powers to cover up crime and to harass those he perceived to be enemies. ${ }^{84}$ The committee rejected an article citing tax evasion. ${ }^{85}$ Some members of the committee thought that this article, by alleging purely personal misconduct, failed to set forth a high crime or misdemeanor. ${ }^{86}$ Others voted against the article for strategic reasons. ${ }^{87}$ Thus, the Committee's action does not represent a clear judgment on whether tax evasion is an impeachable offense. Moreover, even a clear judgment would not have conclusively reflected the judgment of the entire House of Representatives.

5. Early Congresses. Congressional enactments during the Constitution's first decade occasionally employed the phrase "high misdemeanor" outside the context of impeachment. This usage is inconclusive, however, mainly because the Congress employed the phrase only twice. In the seminal Act to Establish the Treasury Department, the First Congress used the phrase in the section defining and proscribing conflicts of interest for the Department's officers. ${ }^{88}$ That statute applied its conflict of interest rule to "person[s] appointed to any office instituted by this act." misconduct position, as the Treasury Act applies exclusively to conduct by federal officers that represents an actual or apparent misuse of their official positions. Yet, there is nothing in the Act itself or the debates surrounding its adoption to indicate that Congress adopted the view that the category "high misdemeanors" must be so limited. It is at least equally plausible that the First Congress made a policy choice to limit the criminal penalties to officers of the Treasury Department.

The third Congress also employed the "high misdemeanors" formulation. It forbade "any person" within the jurisdiction of the United States "to set out on foot or provide or prepare the means for any military expedition" against a foreign sovereign "with whom the United States are at peace." Congress designated any violation to be a "high misdemeanor." This Act plainly applies the category to non-official misconduct. Indeed, its primary object, signified by the open-ended "any person," seems to be private conduct undertaken by private actors. This Act, then, undermines the official misconduct position. While interesting, it is not a very powerful consideration. Early congressional usage of

84. The Judiciary Committee approved three articles of impeachment. The first charged obstruction of justice, the second charged abuse of power, and the third charged contempt of Congress. See VAN TASSELL \& FINKELMAN, supra note 68, at 259.

85. Id.

86. Id.

87. Committee staffer John Labovitz concluded that the committee properly rejected the tax evasion article, not because it failed to allege an impeachable offense, but because presentation and proof would have complicated the case enormously. He cites a number of members who concurred in this view. See JOHN R. LABOVITZ, PRESIDENTIAL IMPEACHMENT 124-25 (1978).

88. 1 Stat. $65, \S 8,1$ st Cong. 1st Sess. (1789).

89. Id.

90. 1 Stat. $31,384, \S 5,3 d$ Cong., 1st Sess. (1794).

91. Id. 
the "high misdemeanor" formulation was too sporadic to be very helpful in elaborating a meaning of the Impeachment Clause.

\section{III}

\section{THE CLINTON IMPEACHMENT}

The usual sources of constitutional meaning - text, structure, history, and practice-do not support the proposition that the scope of impeachable offenses is limited to official misconduct. The position advocated in the law professors' letter, nevertheless, has one last hope. Text, structure, history, and precedent are consistent with an understanding that the meaning of "high Crimes and Misdemeanors" was to be developed over time through a process of interpretation and application similar to the common law. Advocates of the law professors' position might stake out a prescriptive claim that "high Crimes and Misdemeanors" should be understood to embrace official misconduct only." To put it the other way around: Why accept the House's view that "high Crimes and Misdemeanors" refers to all seriously harmful misconduct and is not limited to instances where the harm flows from the exercise of official power?

The Clinton episode offers a powerful response: Private or unofficial misconduct can have serious public consequences_ just as serious as official misbehavior. Whether or not the harms President Clinton caused were so egregious as to warrant his impeachment or his removal from office, ${ }^{94}$ his unofficial conduct undeniably has done serious public harm. As discussed in connection with structural concerns, ${ }^{95}$ the Constitution relies on the President being a strong, energetic, and independent force within the government. ${ }^{6}$ President Clinton's

92. See supra text accompanying note 60. Professor Keith Whittington has developed a theory of extra-judicial constitutional construction that does not require the construction to be continuous. But his approach denied non-continuous constructions significance for judicial or legal interpretations of the Constitution. See WhitTington, supra note 1 , at 181 ; see also id. at 111.

93. The letter itself does not take this approach. It relies mainly on the textual argument noted $s u$ pra text accompanying notes 12-13 and, to a lesser extent, on structure.

94. I will reluctantly express that I do not believe they were. I am reluctant not because I am not firm in this view, but because I do not regard the view of any academic lawyer as peculiarly useful. The question-did the President cause terrible injury to the public and our constitutional system of government such that he should be impeached and removed from office-falls outside the special competence of lawyers. This is quite literally a political question. Constitutional lawyers, including law professors, can help formulate the question. We have a special competence in understanding the quality of offense that the mechanism of impeachment is designed to counter and of the risks to the structure of government of applying that mechanism too quickly or too grudgingly. But see RICHARD POSNER, AN AFFAIR OF STATE 240-45 (1999) (noting that there is reason to question whether special competence was demonstrated during the Clinton impeachment proceedings): Michael J. Klarman. Constitutional Fetishism and the Clinton Impeachment Debate, 85 VA. L. REV. 631 (1999). But the answer to the question involves factual, political judgment-whether a particular course of conduct in fact has caused or will cause injury of the sort that the Constitution contemplates.

95. See supra text accompanying notes 19-22.

96. Practice heightens the significance of these qualities in the modern presidency. Political scientists debate whether the central role that Presidents have come to occupy is based on the power of persuasion or the power to engage in unilateral action. Compare RICHARD NEUSTADT, PRESIDENTIAL POWER (1960) (locating presidential power in the "bully pulpit"), with Terry Moe \& William Howell, 
unofficial misconduct lessened his capacity to perform that role. Consider some obvious examples. When he cites the national interest to deploy the military, there are the nagging questions about "Wag the Dog." "When he exercises the pardon power, there are questions about whether his motive is mercy or political gain. ${ }^{98}$ Because of President Clinton's unofficial misconduct, the charges implicit in these questions have a greater air of plausibility than they would otherwise. This, at the very least, creates distractions from the President's ability to exercise the powers of his office effectively.

After the episode culminating in President Clinton's impeachment and acquittal, it is no longer difficult to imagine a President whose unofficial behavior brings him and the government into such disrepute that it cannot credibly deploy military forces. What for President Clinton have been impairments or distractions could, under different circumstances, become major obstacles. The past is instructive, for it includes cases of unofficial misconduct that renders continued service in office intolerable. ${ }^{99}$ Imagine that William Blount had been elected President of the United States, instead of senator from Tennessee, his unofficial misconduct, if discovered during his hypothetical presidency, could have plunged the nation into war.

Updating the example, the continuance in office of a President with a significantly diminished ability to discharge the powers of his office could be extremely dangerous, whether the diminution stems from official or unofficial misconduct. At this moment in history, it would be far-fetched to conjure the possibility that a diminished President might encourage a foreign power to invade the United States. Nevertheless, it is plausible to anticipate that some foreign powers might be emboldened to advance on other important national security interests.

This turns the question back around: Why would we tolerate such a situation when it arises from unofficial, rather than official, conduct? One response is suggested in the law professors' letter-to preserve the independence and coequality of the executive branch. The formality of an official misconduct requirement might deter Congress from seeking to use impeachment as a means of diminishing the executive branch.

Again, history is useful. Practice through the course of the Constitution's existence demonstrates that Congress does not use impeachment to gain control over the executive, and so there is no obvious need for this formal limit. In its exercise and non-exercise of the impeachment powers, Congress has been at-

The Presidential Power of Unilateral Action, 15 J. L. ECON. \& ORG. 132 (1999). Whatever its basis, the presidency is central to the constitutional project of defining and securing the national interest.

97. See, e.g., Elaine Scolino \& Ethan Bronner, Crisis in the Balkans: the Road to War, N.Y. TIMES, at 1 (Apr. 4, 1999).

98. See, e.g., Charles Babington \& David Vise, Clinton Explains Clemency; Politics Had no Role in Decision, President Tells House Members, WASH. Post, at A2 (Sept. 22, 1999); Michael Kelly, Puerto Rico Surprise, WASH. POST, at A23 (Sept. 1, 1999).

99. See supra text accompanying notes 66-83 (discussing the cases of Senator William Blount, Judge West Humphreys, and Judge Harry Claiborne). 
tentive to the Constitution's structure and to the independence and coequality of the executive. The major possible exception is the impeachment of Andrew Johnson, but there, the articles of impeachment condemned President Johnson's official behavior, so this formalistic limit would not have helped preserve the balance of power. ${ }^{100}$

My point in raising the Johnson impeachment is simply that, if a Congress does not care about the independence and coequality of the President, an official conduct limit will not stop it. In the more characteristic circumstance, where Congress does care about, and is attentive to, constitutional structure, the formal limit of official conduct is not necessary and may render the remedy of impeachment unavailable in cases where a President's unofficial conduct causes serious public harm.

IV

\section{CONCLUSION}

The usual sources of constitutional meaning do not support the proposition that the scope of impeachable offenses is limited to official misconduct. In fact, they offer strong, though perhaps not conclusive, support for the contrary position. Consideration of the Clinton impeachment demonstrates that there is no meaningful benefit to limiting impeachment to official misconduct, but that there may be real harm. For this reason, the House of Representative's interpretation should be accepted as establishing the precedent that the category of impeachable offenses is not limited to abuses of official power.

100. The same point could be made with respect to the effort to impeach President John Tyler. See VAN TASSEL \& FINKELMAN, supra note 68, at 203. 
